\title{
Oil risk contracts, business conduct and performance patterns: Data panel analysis
}

\section{Contratos de riesgo de petróleo, patrones de conducta y desempeño de empresas: análisis de panel de datos}

\author{
Alejandro Ibarra Yúnez ${ }^{\mathrm{a}, *}$, Fidel Flores Chapa ${ }^{\mathrm{b}}$ \\ ${ }^{\text {a }}$ EGADE Business School, Tecnológico de Monterrey, Mexico \\ ${ }^{\mathrm{b}}$ Escuela de Ingeniería y Ciencias, Tecnológico de Monterrey, Mexico
}

Received 21 June 2016; accepted 16 February 2017

Available online 26 November 2017

\begin{abstract}
Using the economic and financial performance data of international companies for the exploration, and exploration-extraction (E\&E) of oil, as well as the patterns of institutional situation and orientation with the government market and national oil companies or NOCs that receive project offers, we analyze the institutional development and behavior patterns by type of E\&E contract, following the strategic actor approach, or the so-called agency theory. Additionally, in light of Mexico's energy reform being implemented between 2015 and 2019, we analyzed the types of license contracts compared to those for production and shared profit. Subsequently, it was determined-through panel data methods in the analysis of 17 companies between 2005 and 2015-that global companies present bigger yields and commitments compared to specialized companies, confirmed by their net income and returns on equity or ROE.

(C) 2017 Universidad Nacional Autónoma de México, Facultad de Contaduría y Administración. This is an open access article under the CC BY-NC-ND license (http://creativecommons.org/licenses/by-nc-nd/4.0/).
\end{abstract}

JEL classification: L51, C78, L71, C23

Keywords: Regulations economy; Negotiation models; Oil exploration; Panel data models

\section{Resumen}

Usando datos del desempeño económico-financiero de las compañías internacionales de exploración y exploración-extracción (E\&E) de petróleo o IOCs, así como los patrones de situación institucional y

\footnotetext{
* Corresponding author.

E-mail address: aibarra@itesm.mx (A.I. Yúnez).

Peer Review under the responsibility of Universidad Nacional Autónoma de México.
} 
orientación con el mercado de gobiernos y empresas nacionales de petróleo o NOCs receptoras de ofertas de proyectos, se analiza el desarrollo institucional y los patrones de conducta por tipo de contrato de E\&E, siguiendo el enfoque de actor estratégico, o la llamada agency theory. Adicionalmente, ante la reforma energética de México en proceso de implementación entre 2015 y 2019, se analizan los tipos de contratos de licencia frente a los de producción y utilidad compartida. Luego, utilizando métodos de panel de datos en análisis de 17 empresas entre 2005-2015, se determina que las empresas llamadas globales presentan rendimientos y compromisos mayores frente a las especializadas, demostrados por sus ingresos netos y rendimientos sobre capital o ROE.

(C) 2017 Universidad Nacional Autónoma de México, Facultad de Contaduría y Administración. Este es un artículo Open Access bajo la licencia CC BY-NC-ND (http://creativecommons.org/licenses/by-nc-nd/4.0/).

Códigos JEL: L51, C78, L71, C23

Palabras clave: Economía de las regulaciones; Modelos de negociación; Exploración de petróleo; Modelos de datos en panel

\section{Introduction}

Several oil-producing countries have opened their oil exploration and extraction (E\&E) sector to the investment of global or international oil contractor companies, known as IOCs, ${ }^{1}$ through different types of agreements (Al-Attar \& Alomair, 2005) as was done by Mexico with the Energy Reform (RE, for its acronym in Spanish) in 2014, after almost 80 years of depending on its state company, Pemex, and investing its national capital in the development of the sector.

The deregulation and opening to the private initiative answers to the need of the governments to share investment risks (Feng, Zang, \& Gao, 2014) and, at the same time, strengthen the sector with the transfer of technology, experience and capital of the IOCs contractor companies, whether alone or co-investing with domestic private oil companies or POCs. In recent years, the majority of countries that keep their oil sector nationalized have decreased their production and decelerated exploration, due to the lack of appropriate technology and experience, as well as institutional limitations and policies (Al-Attar \& Alomair, op. cit. 2005), especially with effects in investment restrictions. With this, the economic reason seems to be fundamental in the understanding of the actions of regulatory reforms and the isolation of global companies in E\&E.

The limitations of the reformed state-owned company: Pemex, now a productive company of the state, are present in Mexico, where the income of the State heavily depends on oil revenues, and due to the need to deal with other sectors, the investment is less than required in the exploration of hydrocarbons in order to ensure high levels of production in the future. The intention is to remedy this lack of capital through the participation of IOCs and POCs.

The constitutional decree of the RE indicates that, in order to carry out the activities of E\&E of solid, liquid or gas hydrocarbons-including the activities that State companies could perform with private individuals-they should be done through contracts under the terms of article 27 of the Constitution (D.O.F., 2013), this in the interest of the State to maintain the sovereignty of the resources and guarantee the control and observance of oil activities.

\footnotetext{
${ }^{1}$ In this article, when speaking of IOCs, the term should be understood as any legal entity with the possibility to be a contractor. Therefore, the concept is broad and includes national private oil companies or POCs, as well as sub-contracts of the co-investment type, national or foreign.
} 
The same decree establishes that the contracts for oil E\&E can be: (a) service contracts (SC); (b) profit sharing contracts; (c) production sharing contracts (PSC); (d) license contracts (LC); and (e) Any combination thereof. In each case, the State will define the contractual model that best fits to maximize the country revenue. The law will establish the modalities of the considerations that the State will pay to its productive companies or to the private individuals for the E\&E activities of oil and other hydrocarbons.

Among other consideration modalities, the following are regulated: (a) in cash, for service contracts; (b) with a percentage of the profit, for the profit sharing contracts; (c) with a percentage of the production, for production sharing contracts; (d) with the onerous transfer of the hydrocarbons once they have been extracted from the underground, for license contracts; and (e) any combination thereof.

There is an especially critical challenge for countries that have deregulated their energy sector. The objective of this study is to provide both a theoretical and empirical foundation regarding E\&E oil contracts with an established or incumbent company, now defined as State-owned Production Company, PEMEX, and with private participants that have investment and technological capabilities, both from national private companies and global companies with different types of productive specialization in oil businesses, or IOCs, something that is new for Mexico. The analysis first typifies, in a theoretical manner, the behavior patterns of contractor companies, based on the preferences of the same and the host governments, to then empirically link their performances measured in net income and ROE, with the behavior patterns derived from global IOCs when compared to specialized ones.

According to Jaffe and Soligo (2007), approximately $33 \%$ of all E\&E contracts in the world are between a host government (HG) and its NOC, with the corresponding IOC. This means that concentrated markets characterize the international contract market. Therefore, the analysis is justified based on terms of strategic actors with an agency theory approach.

The study is divided in the following manner: The following section revises the relevant literature on E\&E contracts from the perspective of the strategic actor. The third part focuses on presenting the reference framework of the contracts, from the union of the explicit motivation approaches of the governments and the contractor IOCs, and the theoretical models of production sharing contracts, licenses and risk services with re-purchase are developed, as well as the balances for governments in comparison to contractors with an optimal contract type. The fourth section uses the data of the IOCs and the types of governments to derive the validation of the algebraic models of the previous section with data pooling and panel analyses. In this empirical section, the economic (net income of the companies) and financial (ROE) performances are proven, with the types of global companies compared to those specialized in their behavior patterns. The fifth section concludes and derives the implications for Mexico.

\section{Relevant literature on international oil contracts}

The literature on oil E\&E contracts is scarce, given that many contracts between governments and their national oil companies (NOCs), with international contractors or private groups, have been carried out in a bilateral manner, with little transparency and where NOCs are not public companies listed in stock markets. For their part, the IOCs contractors, by not being public companies or developing public projects, do not very often disclose their financial information or the information of the projects. Therefore, initiatives from non-governmental groups, such as the Extractive Industry Transparency Initiative (EITI), have arisen, seeking since 2003 to publicize the information of all contracts and tax dealings and royalties of the world extractive projects; 
however, it only has the support of a group of around 40-member countries: The United States, the European Union, Norway, several countries in Africa, as well as Kazakhstan, Kyrgyzstan, Tajikistan, and some countries in Asia (EITI, 2016).

Despite the above, the modeling of international E\&E contracts, in terms of the game and optimization theory, has been addressed in the works of Al-Attar and Alomair (2005) on contractual alternatives for NOCs with respect to contractor companies; Feng et al. (2014) and Ghandi and Lin (2014) make comparisons between destination countries, according to the strategic assets seen by the contractor companies; Jenik (2005) focuses on the fiscal aspect; and Johnston (2003) and Van Groenendaal and Mazraati (2006) use more comprehensive contractual models. All the works mentioned above depart from Laffont basis regarding the objective functions of the governments (welfare with or without taxes) compared to the regulated companies that maximize profit, considering the variables of adverse selection and cost reduction efforts as endogenous, since they are variables that are not observed by the government or regulator (Laffont, 2005).

\section{E\&E contracts: agent-based approach}

\section{Motivations of the players in their objectives}

Oil concessions and contracts are bilateral legal instruments through which the rights and obligations of the company or group of companies (contractor) and the State (contracting) are established. There are different contracting schemes used around the globe by the host governments to allow IOCs to carry out oil explorations and, in the case of a commercial discovery, to invest in the development and exploitation of the oil field. These types of contract have been analyzed by the economic theory, institutional theory, strategy theory, and by the game and bi-level optimization theory.

A petroleum fiscal regime refers to the terms and conditions established in a mutual agreement contract between the government and the IOC. It is comprised of payments done under the concept of taxes and rights that the IOC or POC has and the State (generally through its NOC) and which implies obligations for both parties. To design a fiscal system, the countries consider the legal framework related to the oil resources, the development strategies, the activities to stimulate, and the experiences obtained, thus each regime possesses characteristics that differentiate it from the rest. Isehunwa and Uzoalor (2011) define fiscal regimes as the framework to administer, regulate and share oil income, thus they are important for the host government or HG, and for the IOCs.

According to Jenik (2005), the governments of the productive countries basically have three ways of making use of their fossil resources:

(a) Through a state company that can carry out the E\&E of hydrocarbons and, in some cases, all the activities of the sector productive chain (vertically integrated company). Such is the case for countries as Saudi Arabia, Venezuela and Iran;

(b) Through private investment, making use of several companies specialized in specific activities and/or integrated oil companies, as is done in the United States, Russia, the United Kingdom and Canada; and

(c) Through the combination of the two previous systems, as is the case of Indonesia, Nigeria, Azerbaijan, Kazakhstan and Mexico, since the RE.

Al-Attar and Alomair (2005) divide the history of oil agreements into three main eras. First, the era of concessions, when IOCs dominated the oil sector globally through classic concession 
agreements in different parts of the world. Subsequently, the economic nationalism era began, when the creation of state oil companies or NOCs proliferated, as well as the appearance of new types of oil agreements. Finally, we arrive to current times, in which countries have re-opened their oil upstream sectors to private investment.

For his part, Johnston (2003) proposes that petroleum fiscal regimes can be divided into two types according to the ownership of the oil: systems based on the enforcement of royalties and taxes (concessions), where the IOC owns the oil, and a contract system where the State retains the sovereignty of the resources.

The contractual system is in turn sub-divided according to the type of contract: services contracts (SC) and production and shared utility contracts (PSC). In turn, service contracts can be of two types: pure-service contracts and risk-service agreements (RSA), in terms of risk assignation between the host government and the IOC. Furthermore, there are Buy-Back Contracts or BuyBack Agreements (BBA), which are a particular type of risk-service agreement (Van Groenendaal \& Mazraati, 2006). Another agreement that could be included is the license contract ${ }^{2}$ (LC).

According to Le Leuch (1988), the contract model selected by a government, as well as the terms and conditions agreed upon between the signatory parties, mainly depend on the policies of the host country and on the negotiation capabilities of the governments. At the same time, they are directly related to the exploitation potential of the offered surface and to the situation of the international oil market. Additionally, given that the contractor (IOC/POC) has the variables of "effort" and adverse selection as private information, it becomes the agent or "strategic actor," compared to the HG that takes the role of the "Main" agent (King \& Spalding, 2005).

On the other hand, the total costs of E\&E, as well as the recovery factor are two main factors that determine the type of oil contract that the HG will adopt. For example, in countries with relatively low reserves and high production costs due to the fact that oil is in ultradeep waters, as is the case for the United Kingdom, the United States and Norway, the pervasive system is the one of royalties and taxes. Conversely, when the reserves are big and the costs moderate, as is the case of Kazakhstan, Oman, China, Indonesia and Nigeria, the production-sharing agreements are more frequent. Whereas the pure-service and risk-service agreements (RSA) tend to be used in countries with big reserves and low E\&E costs, as is the case of Kuwait, Iran and Venezuela.

However, some countries, such as Mexico, have adopted more than one type of oil agreement given that they have distinct oil reserves, with a broad range of E\&E costs. Furthermore, it is logical for the host country to offer a portfolio of contract types in a set of asymmetric information, so that IOCs can be selected automatically, according to their behavior patterns regarding the acceptance or aversion to risk and their characteristic as global companies or companies specialized in some part of E\&E (constructor, transporters, specialized in deep waters, etc.).

Moreover, given that the main objectives of HGs are to maximize the wealth of their fossil resources (Blake \& Roberts, 2006) and to have control of the oil activity, they resort to the establishment of work commitments and to certain fiscal systems (Ashong, 2010). For example, payments are made, argumentatively incentivized, through bonuses after signing the contract, and during the production through royalties, taxes, and a share in the production or profits. On the other hand, the IOC seeks the maximization of its wealth through the search of oil reserves and the production of hydrocarbons at the lowest cost and the highest possible benefit margin in the shortest time (Johnston, 1994).

\footnotetext{
${ }^{2}$ License contracts are a particular type of contract equivalent in terms to a combination between a modern concession and a production-sharing contract.
} 
According to Grunstein (2010), and Feng et al. (2014), the interests that can be observed in the contracts respond, at the very least, to the following:

On the side of host governments (HGs):

- Maximization of the oil revenue

- Increase of the national reserves

- Control of the operations through work commitments

- Assurance of the national supply (energy security)

- Technological development of the industry and national content

- Environmental protection and guarantee of the existence of reserves in case of accidents

On the side of the contractors (IOCs/POCs):

- Proportionality between the risk of the project and the compensation

- Maximization of the profit

- Accounting of the reserves

- Contractual flexibility and regulatory stabilization

- Recovery of investment costs

- Less administrative control of the HG on the contract

- Capacity for international arbitration

\section{Presentation of the theoretical behavior models}

Elaborated from the models by Feng et al. (2014), as well as by Laffont (2005), the alternative models could be developed as follows. Compare the characteristics of each type of contract, starting with the production-sharing contract (PSC), then presenting the license contract (LC), and then adding the risk-service with Buy-Back Agreement (BBA) to contrast and derive those theoretically preferable.

\section{Production-sharing contract (PSC)}

Be the gross income $I_{B}$ defined as the $Q$ extracted volume multiplied by its $P$ price, both expected variables

$$
I_{B}=P Q
$$

The amount per royalties ${ }^{3} R$ is the product of the percentage of royalties $\alpha$ multiplied by the gross income

$$
R=\alpha I_{B}
$$

Replacing Eq. (1) in Eq. (2):

$$
R=\alpha P Q
$$

\footnotetext{
${ }^{3}$ In the case of Mexico, the percentage of royalties is different for each type of hydrocarbon and depends on the prices of each one. For simplification purposes, the approach by Feng et al. (2014) is followed, so that the percentage of royalties is the same for all products and is directly applied to the gross income according to international practice.
} 
The recovery cost rate $C R$ is the percentage $\sigma$ of the cost recovery limit, multiplied by the remnant of the gross income once the royalties have been subtracted, offered by the HG and calculated within the viability by the IOC agent (cost oil):

$$
C R=\sigma\left(I_{B}-R\right)
$$

Replacing Eqs. (1) and (3) in Eq. (4), the following is obtained:

$$
C R=\sigma(1-\alpha) P Q
$$

The total operative profit $U O_{T}$ is the result of subtracting the remnant percentage of the royalties and the percentage of the cost recovery (Eq. (4)) from the gross income:

$$
U O_{T}=I_{B}-R-C R
$$

Replacing Eqs. (1), (3) and (5) in Eq. (6), the following is obtained:

$$
U O_{T}=(1-\sigma)(1-\alpha) P Q
$$

The amount of the operating profit for the IOC $U O_{I O C}$ will be obtained by multiplying the distribution percentage $\delta$ by the total operating profit

$$
U O_{I O C}=\delta U O_{T}
$$

Replacing Eq. (7) in Eq. (8), the following is obtained:

$$
U O_{I O C}=\delta(1-\sigma)(1-\alpha) P Q
$$

The distribution rate $(\delta)$ is variable and subject to negotiation between the HG or main agent, and the strategic IOC agent. For its part, the IOC must pay a tax rate $\mu$ on its operating profit

$$
T_{P S C}=\mu U O_{I O C}
$$

Replacing Eq. (9) in Eq. (10), the fiscal tax rate is obtained in terms of the other percentages of the gross income:

$$
T_{P S C}=\mu \delta(1-\sigma)(1-\alpha) P Q
$$

The total income of the IOC $I_{I O C}$ after taxes is:

$$
I_{I O C, P S C}=U O_{I O C}+C R-T_{P S C}
$$

Replacing Eqs. (5), (9) and (11) in Eq. (12), the following is obtained:

$$
I_{I O C, P S C}=(1-\alpha)[\delta(1-\mu)(1-\sigma)+\sigma] P Q
$$

The cost recovery rate has the purpose of covering the operating expenses $O P E X$. Given that the IOC assumes these costs, the net income of the IOC $U_{I O C}$ is reduced to:

$$
* U_{I O C, P S C}=(1-\alpha)[\delta(1-\mu)(1-\sigma)+\sigma] P Q-O P E X
$$

Take the aforementioned equation as the first type of balance of this PSC contract, and point it out with an asterisk $(*)$ 


\section{License contracts $(L C)$}

The gross income $I_{B}$ and the amount of royalties $R$ are calculated the same way as a PSC (Eqs. (1) and (3)), that is, royalties are subtracted from the gross income, and from this remnant a percentage $\omega$ is for the $\mathrm{HG}$, which will correspond to the profit of the $\mathrm{HG} G_{H G}{ }^{4}$

$$
G_{H G}=\omega\left(I_{B}-R\right)
$$

Replacing Eqs. (1) and (3) in Eq. (15), the following is obtained:

$$
G_{H G}=\omega(1-\alpha) P Q
$$

The IOC receives the onerous transfer of the hydrocarbons once the considerations of the HG have been paid, thus the total income of the IOC $I_{I O C, L C}$ is:

$$
I_{I O C, L C}=I B-R-G_{H G}
$$

Replacing Eq. (16) in Eq. (17), taking into consideration Eqs. (1) and (3) so that the percentages or fractions are clearly defined to the right of the equation, the equation is synthesized as follows:

$$
I_{I O C, L C}=(1-\omega)(1-\alpha) P Q
$$

The IOC assumes the entirety of the operating expenses $O P E X$, therefore, its operating profit is reduced to:

$$
U O_{I O C, L C}=(1-\omega)(1-\alpha) P Q-O P E X
$$

The tax rate $\mu$ on its operating rate is:

$$
T_{L C}=\mu U O_{I O C, L C}
$$

Replacing Eq. (18) in Eq. (20), the following is obtained:

$$
T_{L C}=\mu[(1-\omega)(1-\alpha) P Q-O P E X]
$$

The net income of the IOC $U O_{I O C}$ is obtained by subtracting the taxes from its operating profit

$$
U_{I O C}=U O_{I O C}-T_{L C}
$$

Replacing Eqs. (18) and (21) in Eq. (22), results in a second balance

$$
* * U_{I O C}=(1-\mu)[(1-\omega)(1-\alpha) P Q-O P E X]
$$

Take the last equation as the second type of balance of this LC contract and point it out with two asterisks $(* *)$

\section{Risk-service agreement (with Buy-Back or BBA)}

The gross income $I_{B}$ is obtained the same way as the previous models (see Eq. (1)).

The operating expenses $O P E X$ must be subtracted from the gross income, and a remnant percentage $\varphi$ determines the income of the government or HG $G_{H G, B B A}$

$$
G_{H G, B B A}=\varphi\left(I_{B}-O P E X\right)
$$

\footnotetext{
${ }^{4}$ Alpha is the percentage of royalties, while the omega is the distribution of the production. The delta and omega coefficients could be considered similar for the IOC. Phi is seen from the point of view of the HG.
} 
Replacing Eq. (1) in Eq. (24), the income of the government is:

$$
G_{H G, B B A}=\varphi(P Q-O P E X)
$$

For its part, the operating profit of the IOC $U O_{I O C}$ is expressed in the following manner:

$$
U O_{I O C, B B A}=(1-\varphi)(P Q-O P E X)
$$

This payment to the IOC includes the amortization of the investment $\beta C A P E X$, the payment of bank charges $C B$, and the remuneration to the IOC which in this case is equivalent to the net income of the IOC $U_{I O C, B B A}$, which is reduced to the third balance as follows:

$$
* * * U_{I O C, B B A}=I_{I O C, B B A}-\beta C A P E X-C B
$$

Finally, take this balance of the BBA contract and point it out with three asterisks (***).

Where $\beta$ is the depreciation. The income of the IOC is tax free. Note that the models assume results without differences between exploration, extraction and production times, that is, they are simultaneous sets at a single moment in time.

Therefore, the definition of percentages is as follows:

$\alpha$ is the percentage of royalties;

$\omega, \delta$ are defined as distribution percentages of the profit or production over gross incomes (LC) or over the operating profit (PSC), corresponding to IOCs;

$\sigma$ is the maximum percentage of the recognizable income for the recovery of costs or cost oil in PSCs;

$\mu$ is the corporate income tax;

$\beta$ is the capital depreciation percentage in CAPEX; and finally

$\varphi$ is the percentage of the corresponding income to the HG and $(1-\delta)$ is the remnant for the IOC.

In accordance with the above, it is clear that the risk-service contracts with Buy-Back (BBA) are inferior to the license contracts (LC) and to the production-sharing contracts or PSC, both for the government and for the contractor company, given that $\varphi(P Q-O P E X)<\omega \mu P Q$ divided by BBA and LC. This is also the case for the contractor, $* * *<* *$.

Now, between PSCs and LCs, LCs could be more advantageous for the government than PSCs, but not so for the IOC. This means that it could be assumed that $\omega \mu \alpha P Q>\mu \alpha(1-\sigma)(1-\delta) P Q$. On the side of the IOC, $*{ }^{*} * *$, but conditioned to the distribution percentage being high as well as the recovery cost oil percentage being attractive. In other words, the aforementioned percentages must be assumed to clearly obtain from this analysis that $* * *>* * *$ for the IOC.

Visually, the developed proposals can be summarized as follows (Fig. 1).

It seems clear that for the IOC, the * type contracts will be entirely preferable to the ** type contracts, and in turn those will be preferable to the *** type contracts. However, even though for the government or HG the *** type dominates over the others, there is such a level that the * type is preferable to ** type and in other cases of low net income for the IOC, ** is preferable to $*$. The types of contract will now be preferable by the type of contracting companies: global or specialized. The empirical analysis is done in the following section.

\section{Company behavior and performance: panel data analysis}

There is no detailed and sufficient information of all contracts at a global level, nor is there a known universe of companies specialized and active in E\&E contracts, given that several of them 


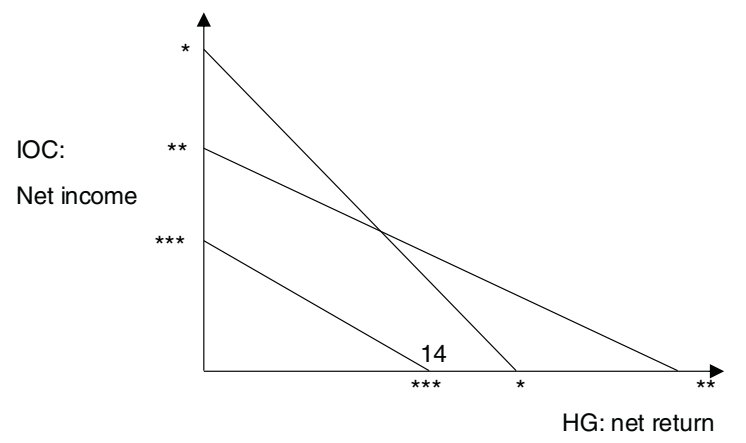

Fig. 1. Net Benefits by Types of E\&E Contract: International Oil Companies (IOC) and host government (HG). Source: Own elaboration.

are not listed in the equity markets and not all E\&E activity is done through contracts such as the ones described, because many oil producing countries retain the governmental ownership of their own NOCs. Similarly, there can be companies that accept different types of E\&E contracts depending on the host governments. However, using alternative panel data analysis specifications, it is possible to prove a portion of the hypothesis of this study, as described below.

The aim is to separate the companies by origin and coverage level, focusing on the so-called global and E\&E specialized companies, as well as on their financial performance variables, and size through the asset variable, to approach the trend regarding types of contracts due to the fact that it is not possible to carry out an equity risk analysis or measured yields in financial markets (OECD, 2012).

The companies can be separated by subsector within the hydrocarbons chain. When using the classification of a study by Mittal, Dholakia, Han, and Dayal (2015) for companies in the US, it is evident that this is a high technology market, with big capital and financing requirements; therefore, it is a concentrated company sector and of the oligopoly kind (Mittal et al., 2015). The contractor companies are the following (Table 1):

The following validation analysis of the exposed theory focuses on the first two classifications and where there are economic and financial data from 17 companies described in the periods of 2005-2015. It deals with eight global companies and nine companies specialized in E\&E, using standardized information from Thomson Reuters and Bloomberg, consulted online during November, 2016. The capacity of income on assets of the big global companies and the return on

Table 1

Classification of oil companies by subsector.

\begin{tabular}{ll}
\hline Integrated IOCs (global) & BP, Chevron, Conoco Phillips, Exxon Mobil, Shell, Statoil, Total, ENI \\
IOCs specialized in E\&E & Anadarko Petroleum, Apache, EOG \\
& Resources, Hess, Marathon Oil, Murphy Oil, Newfield Exploration, Noble \\
& Energy, and Occidental Petroleum \\
Midstream oil and gas & Buckeye Partners, Enbridge Energy \\
& Partners, Enterprise Products Partners, Genesis Energy, Kinder Morgan, Plains \\
& All American Pipeline, Spectra Energy, Sunoco, and Targa Resources \\
IOCs specialized only in & Baker Hughes, Cameron, Dresser-Rand, \\
services and construction and & FMC Technologies, GE Oil \& Gas, Halliburton, Hercules Offshore, MRC Global, \\
maintenance & National Oilwell Varco, Newpark Resources, Oceaneering, Oil States \\
& International, Parker Drilling, Schlumberger, Transocean and Weatherford
\end{tabular}

Source: Elaborated by the authors with data from Mittal et al. (2015). 
net equities or ROE are the dependent variables. The panel model could be specified in a general manner as follows:

$$
\hat{y}_{i t}=\boldsymbol{w}_{i t} \hat{\boldsymbol{\theta}}+\hat{u}_{i t}
$$

where the estimators correspond to the alternative transformations for est $y_{i t}$, $\boldsymbol{w}_{i t}$ and where $u_{i t}$ of $y_{i t}$ and $w_{i t}^{\prime}=\left[1 x_{i t}^{\prime}\right], u_{i t}$. In this specification, est $y_{i t}$ is the only known function of $y_{i_{1}}, \ldots, y_{i_{T}}$, and in a similar manner the same structure is given for $\boldsymbol{e s t} \boldsymbol{w}_{i t}$ and est $u_{i t}$.

The panel models must be adjusted due to statistical efficiency problems of possible heteroscedasticity and serial correlation of estimation errors. Similarly, for consistent estimators, models with fixed effects or dummies are estimated by type of Global company versus Specialized company in balanced panel estimations of (i) pooled OLS or POLS; (ii) WLS based on the variances of consistency errors; (iii) panel with data out of median or Within Panel; (iv) temporary first difference panel or First Diff; and (v) GLS transformations of the Koyck type or random effects GLS or RE-GLS (Cameron \& Trivedi, 2005).

From the above general specification, POLS implies that $\boldsymbol{\theta}=\left[\boldsymbol{\alpha} \boldsymbol{\beta}^{\prime}\right]$. For panel models with data out of median, est $y_{i t}=\left(y_{i t}-\bar{y}_{l}\right)$, est $\boldsymbol{w}_{i t}=\left(\boldsymbol{x}_{i t}-\overline{\boldsymbol{x}}_{\boldsymbol{l}}\right)$ and $\boldsymbol{\theta}$ is equal to the coefficients of the regressors that change in time. Similarly, the panel model in first differences is specified with the special case of the above-mentioned model, for First Diff. Finally, the case of RE-GLS, est $y_{i t}=\left(y_{i t}-\mu \bar{y}_{l}\right)$, est $\boldsymbol{w}_{i t}^{\prime}=\left(\boldsymbol{w}_{i t}-\boldsymbol{\mu} \overline{\boldsymbol{w}}_{l}\right)$.

The results are show in Table 2 below, and the econometric results are in Tables 3 and 4:

The models are separated into two according to the ROE dependent variables on the one hand, and the Net Operating Income, on the other. One control variable is the size measured by the asset value, which in the first estimations does not seem to be significant, and even presents a

Table 2

Main statistics, using observations 1:01-17:11, Sample of 17 companies between 2005 and 2015. The monetary data is in millions of dollars (USD).

\begin{tabular}{lcccc}
\hline Variable & Mean & Median & Minimum & Maximum \\
\hline roe & 12.3187 & 15.3091 & -162.221 & 41.2868 \\
netincome & 7675.64 & 3486.94 & $-23,119.0$ & $45,220.0$ \\
assetsize & $111,674.0$ & $56,259.0$ & 4768.00 & $357,512.0$ \\
globalspec & 0.470588 & 0.00000 & 0.00000 & 1.00000 \\
USEU & 0.705882 & 1.00000 & 0.00000 & 1.00000 \\
& & & & Asymmetry \\
Variable & Typical dev. & C.V. & -4.35113 & 28.4596 \\
roe & 21.9379 & 1.78086 & 1.14447 & 1.62724 \\
netincome & $11,050.9$ & 1.43973 & 0.824450 & -0.568041 \\
assetsize & $103,803$. & 0.929514 & 0.117851 & -1.98611 \\
globalspec & 0.500474 & 1.06351 & -0.903696 & -1.18333 \\
USEU & 0.456868 & 0.647230 & & Missing observations \\
Variable & Perc. $5 \%$ & Perc. $95 \%$ & IQ range & 0 \\
\hline roe & -21.4355 & 33.9570 & 14.9624 & 0 \\
netincome & -4485.91 & $31,165.8$ & $12,682.5$ & 0 \\
assetsize & 7597.73 & $332,698$. & $158,661$. & 0 \\
globalspec & 0.00000 & 1.00000 & 1.00000 & 0 \\
USEU & 0.00000 & 1.00000 & &
\end{tabular}

Note: Own generation using the database from the GRETL statistical package. 
Table 3

Panel data analysis: ROE dependent variable. Obs: $187 ; j=17$ (8 global companies and 9 specialized in one sample); $t=11(2005-2015)$.

\begin{tabular}{|c|c|c|c|c|c|c|}
\hline & $\mathrm{C}$ & ASSETSIZE & GLOBAL/SPEC & ADJ $R^{2}$ & LOGLIK & AV. ROE \\
\hline $\begin{array}{l}\text { MOD 1: OLS corrected } \\
\text { for heteroscedasticity } \\
\text { after the White test }\end{array}$ & $\begin{array}{l}8.5375^{* * *} \\
(3.65)\end{array}$ & $\begin{array}{l}-9.904 \mathrm{e}^{-06} \\
(0.48)\end{array}$ & $\begin{array}{l}10.7924^{* *} \\
(2.35)\end{array}$ & 0.0486 & -439.575 & 12.32 \\
\hline $\begin{array}{l}\text { MOD 2: WLS based on } \\
\text { error variance }\end{array}$ & $\begin{array}{l}12.9187^{* * *} \\
(7.37)\end{array}$ & $\begin{array}{l}-3.565 \mathrm{e}^{-05^{* *}} \\
(2.52)\end{array}$ & $\begin{array}{l}12.587^{* * *} \\
(3.76)\end{array}$ & 0.0643 & -260.847 & \\
\hline $\begin{array}{l}\text { MOD 3: GLS data } \\
\text { out of median }\end{array}$ & $\begin{array}{l}0.0002^{*} \\
(1.78)\end{array}$ & $\begin{array}{l}-0.00013^{* *} \\
(2.67)\end{array}$ & $\begin{array}{l}10.792^{* *} \\
(2.36)\end{array}$ & \multicolumn{3}{|c|}{$\begin{array}{l}0.161 \text { LSDV-825.949 } \\
0.030 \text { Intra }\end{array}$} \\
\hline $\begin{array}{l}\text { MOD 4: FIRST DIFF } \\
\text { in } t\end{array}$ & $\begin{array}{l}-7.997^{* * *} \\
(4.95)\end{array}$ & $\begin{array}{l}5.067 \mathrm{e}^{-04 * * *} \\
(4.264)\end{array}$ & $\begin{array}{l}2.00^{* *} \\
(2.38)\end{array}$ & \multicolumn{3}{|c|}{0.107 Intra-740.597 } \\
\hline
\end{tabular}

Note: ${ }^{*}$ means variables at $10 \%$ significance; ${ }^{* *}$ means variables at $5 \%$ significance; ${ }^{* * *}$ means variables at $1 \%$ significance Original data from Bloomberg and Thompson-Reuters in US dollars. In the estimations, the standard errors are robust when compared to heteroskedasticity and serial correlation. ROE is return on equity; ASSETSIZE in amount of assets in millions of USD; GLOBAL/SPEC is dummy, where 1 is assigned to global and zero to specialized.

Table 4

Panel data analysis: dependent variable: net income. Obs: $187 ; j=17$ (8 global companies and 9 specialized in one sample); $t=11(2005-2015)$.

\begin{tabular}{|c|c|c|c|c|c|c|c|}
\hline & $\mathrm{C}$ & ASSETSIZE & GLOBAL/SPEC & & $\mathrm{ADJ} R^{2}$ & LOGLIK & AV. NI \\
\hline $\begin{array}{l}\text { MOD 1: OLS corrected } \\
\text { for heteroscedasticity } \\
\text { after the White test }\end{array}$ & $\begin{array}{l}-661.732 \\
(1.643)\end{array}$ & $\begin{array}{l}0.0622^{* * *} \\
(5.089)\end{array}$ & $\begin{array}{l}2209.95 \\
(1.208)\end{array}$ & & 0.3400 & -448.606 & 7675.04 \\
\hline $\begin{array}{l}\text { MOD 2: WLS based on } \\
\text { error variance }\end{array}$ & $\begin{array}{l}-329.958 \\
(1.394)\end{array}$ & $\begin{array}{l}0.0575^{* * *} \\
(6.517)\end{array}$ & $\begin{array}{l}2034.77 \\
(1.278)\end{array}$ & & 0.5164 & -259.746 & \\
\hline $\begin{array}{l}\text { MOD 3: GLS data } \\
\text { out of median }\end{array}$ & $\begin{array}{l}-1393.33^{* * *} \\
(3.237)\end{array}$ & $\begin{array}{l}0.0622^{* * *} \\
(5.080)\end{array}$ & $\begin{array}{l}2209.95^{* *} \\
(2.208)\end{array}$ & & 0.3401 & -448.666 & \\
\hline $\begin{array}{l}\text { MOD 4: FIRST DIFF } \\
\text { in } t\end{array}$ & $\begin{array}{l}-2380.36^{* * *} \\
(4.95)\end{array}$ & $\begin{array}{l}0.2564^{* * *} \\
(4.264)\end{array}$ & $\begin{array}{l}2156.80^{* * *} \\
(2.38)\end{array}$ & & 0.2541 & -1711.316 & \\
\hline MOD5: RE-GLS & $\begin{array}{l}1389.24^{* * *} \\
(7.619)\end{array}$ & $\begin{array}{l}0.1362^{* *} \\
(4.306)\end{array}$ & $\begin{array}{l}1448.9^{* * *} \\
(10.74)\end{array}$ & $\begin{array}{l}0.631(\mathrm{NI}-1)^{* * *} \\
(8.36)\end{array}$ & 0.6381 & -363.929 & \\
\hline
\end{tabular}

Note: $*$ means variables at $10 \%$ significance; ${ }^{* *}$ Significant variables at $5 \%$ significance; ${ }^{* * *}$ Significant variables at $1 \%$ significance.

Original data generated from Bloomberg and Thompson-Reuters in US dollars. Model 5 uses first differences, where the delayed dependent variable for a period is presented as an explicative variable, as it is done in Cameron and Trivedi (2005). In the estimations, the standard errors are robust when compared to heteroscedasticity and serial correlation.

negative sign. Moreover, it seems clear that the binary variable that separates global (diversified) companies from specialized ones is highly significant in the first panel analysis groups, showing that global companies, being more diversified, tend to look for contracts with a relatively higher risk and greater investment, or more government take. According to the theory, GLS models and First Difference are clearly more consistent than the previous POLS and WLS. The analysis of the panel groups comprises 8 global companies and 9 specialized companies in 11 years of the temporary dimension. The dummy variable takes number 1 for global and 0 for specialized companies. 
For its part, Table 4 presents the performance variable as Net Income, with the explicative variables being the same as in Table 2. One last specification of the panel analysis, in this case of monetary flow, is the RE-GLS model. Once more, the consistent models, GLS and First Differences, as well as the one referred as RE-GLS, are superior to the first POLS and WLS according to the theory (Hausman Tests for the difference of parameters and specifications differences are shown summarized in the different log-likelihood quotients toward fixed effects). The statistical significance stands out, both in the size of the company and in its position as global or specialized, proving the hypothesis derived from the theoretical model that states that behavior patterns according to the type of contracts are related to the types of companies and their performance.

It is worth clarifying that the international oil price variable, though it can be deemed as very important for contracts, operates only with a dramatic fall since 2014 in two years of the complete panel, thus, not including it in this analysis is justified. One test that is not shown here is contrasting the array of panel models that ended in 2013 against the models that ended in 2015. It is preferable to have more data than to introduce said variations in international prices in so few periods. Perhaps with more annual observations, said fall in prices can be evaluated in the future.

Finally, when performing a revision of all the economic and financial indicators on the net margins, the tabular analysis of the original database of the 17 companies shows that in 2005-2007, specialized companies had very superior margins compared to the global companies (of more than $30 \%$ compared to averages of $10 \%$ in the global companies), but that have dramatically deteriorated in recent years.

The fact that companies such as Chevron, Exxon and Total showed positive margins while the rest had a bad performance, particularly in 2015, stands out. However, the recent performance of all specialized companies in general is worse than that of global companies, with very superior margins as indicated a decade ago. All specialized companies had negative net margins in 2015, with an average for the nine specialized companies of $24 \%$ in 2005 (and $11 \%$ in 2014). This information is based on the original database.

\section{Implications and conclusion}

Although it is not possible to carry out an econometric analysis of asset value with high frequency data, it seems clear that the group of integrated global companies presents a better performance than the specialized companies (in E\&E) when using data from the financial balance sheets, cash flow statements, and quotients from the financial analysis that are generally used. An array of alternative panel analysis models: POLS, WELS, First Differences and RE-GLS with two dependent performance variables prove the hypotheses of the work.

Despite the secular tendency of lower performance in the 2005-2015 period in general, the ROE indicators and net income indicators are substantially better among global companies, given that by being integrated and/or diversified, they cover lower performances in some part of the chain value, compared to other areas. For example, in the face of low performance in the extraction and production of crude oil, the low price is an advantage in cost savings in the midstream or downstream portion of the industry.

Furthermore, although some of the specialized companies of the analysis, such as Andarko or Marathon, are more similar to the global companies than their E\&E counterparts, the companies analyzed in this segment show a lower performance as a group in the three indicated variables when compared to the global companies.

What can be concluded from the expected preferences by type of contract? It seems that companies with (a) high technology, (b) capability of financed investment and good financial 
reputation, (c) with the capability to cover risks through integration/diversification, would be oriented toward absorbing more risks but with higher returns, as is the case of production-sharing contracts or PSCs. Conversely, companies with a lower performance and inability to cover risks, will prefer license contracts, as clearly shown in the balances of the behavior pattern analyses through PSC or LC contract preferences.

For host governments, a portfolio of E\&E contract options seems to be an optimal solution for the case of asymmetric information on the type of strategic conduct of the companies that search for E\&E contracts, among which are those in this study. Therefore, when governments offer a group of contract options they allow the self-selection of companies and would increase the number of companies requesting contracts. However, license contracts would attract more investment companies with a greater aversion to risk in pessimistic economic cycles, provided that the number of contracts is abundant, as more uncertainty in the type of project means a lower interest in the investment or investments with lower returns; but as a host government, the hope would be to have the maximum possible attraction of investors.

Finally, it seems clear that the theoretical classification of the characteristics of alternative E\&E contracts, such as those implemented by Mexico's Energy Reform, must follow similar contractual bases as the rest of the world. A subsequent study with more data could break down all variables at a financial, macro, and micro-economic level. Additionally, a HG such as the one of Mexico, will need to internalize the type of risk/company that it will select in the following oil bids and surveys in Mexico.

\section{References}

Al-Attar, A., \& Alomair, O. (2005). Evaluation of upstream petroleum agreements and exploration and production costs. OPEC Review, http://dx.doi.org/10.1111/j.1468-0076.2005.00154.x. Organization of the Petroleum Exporting Countries

Ashong, M. (2010). Cost recovery in prdocution sharing contracts: Opportunity for striking it rich or just another risk not worth bearing. Dundee, United Kingdom: University of Dundee - Centre for Energy, Petroleum and Mineral Law Policy.

Blake, J., \& Roberts, M. (2006). Comparing petroleum fiscal regimes under oil price uncertainty. Resources Policy, 95-105. http://dx.doi.org/10.1016/j.resourpol.2006.08.001

Cameron, A. C., \& Trivedi, P. K. (2005). Microeconometrics: Methods and applications. New York: Cambridge University Press.

Diario Oficial de la Federación DOF. (2013). DECRETO por el que se reforman y adicionan diversas disposiciones de la Constitución Política de los Estados Unidos Mexicanos, en Materia de Energía. Ciudad de México, MX: Diario Oficial de la Federación. Available from: http://www.dof.gob.mx/nota_detalle.php?codigo=5327463\&fecha=20/12/2013

EITI. (2016). El Estándar del EITI, 2016. Oslo: Secretaría Internacional del EITI. Available from: https://eiti.org/files/spanish_eiti_standard_0.pdf

Feng, Z., Zang, S.-B., \& Gao, Y. (2014). On oil investment and production: A comparison of production sharing contracts and buyback contracts. Energy Economics, 42(February), 395-402. http://dx.doi.org/10.1016/j.eneco.2014.01.010

Ghandi, A., \& Lin, C. (2014). Oil and gas service contracts around the world: A review. Energy Strategy Reviews, 3 , 63-71. http://dx.doi.org/10.10161/j.esr.2014.03.001

Grunstein, M. (2010). De la caverna al mercado una vuelta al mundo de las negociaciones petroleras. Ciudad de México, D.F.: CIDAC-Felou.

Isehunwa, S., \& Uzoalor, E. I. (2011). Evaluation of true government take under fixed and sliding royalty scales in Nigerian oil industry. Australian Journal of Basic and Applied Sciences, 5(3), 735-741.

Jaffe, A. M., \& Soligo, R. (2007). The international oil companies. Houston: The James A. Baker III Institute for Public Policy; Rice University.

Jenik, R. (2005). The ABC's of petroleum contracts: License-concession agreements joint ventures and production-sharing agreements. In S. Tsalik, \& A. Schiffrin (Eds.), Covering oil: A reporters guide to energy and development (pp. 61-99). Open Society. 
Johnston, D. (1994). International petroleum: Fiscal systems and production-sharing contracts. Tulsa, United States: PennWell Publishing Corporation.

Johnston, D. (2003). International exploration economics, risk and contract analysis. Oklahoma, United States: PenWell.

King, \& Spalding, L. L. P. (2005). An introduction to upstream government petroleum contracts: Their evolution and current use. $O G E L, 3(1)$. Available from: https://www.ogel.org/article.asp?key=1730

Laffont, J. (2005). Regulation and development. Cambridge: Cambridge University Press.

Le Leuch, H. (1988). Contractual flexibility in new petroleum investment contracts. In B. N. Walde (Ed.), Petroleum investment policies in developing countries. London, United Kingdom: Graham and Trotman.

Mittal, V., Dholakia, U., Han, K., \& Dayal, A. (2015). Sector-level results from the 2015 Strategy and Corporate Performance in the Energy Industry, (SCOPE) study. Houston: Rice University JGSB Energy Industry Initiatives Report. Available from: https://papers.ssrn.com/sol3/papers.cfm?abstract_id=2664064

OECD. (2012). Getting It Right: Una Agenda Estratégica para las Reformas en México. OECD Publishing. Available from: http://www.oecd.org/centrodemexico/Getting\%20It\%20Right\%20EBOOK.pdf

Van Groenendaal, W. J., \& Mazraati, M. (2006). A critical review of Iran's buyback contracts. Energy Policy, 3709-3718. http://dx.doi.org/10.1016/j.enpol.2005.08.011 